International Journal of Advanced Biological and Biomedical Research Available online at http:www.ijabbr.com

Volume 7, Issue 3 (2019) pp. 237-245

Review Article

\title{
Role of Moringa Olifera Leaf Meal on the Growth Performance of Poultry/African Catfish-A Review
}

\author{
J.0. Alagbe \\ Department of Animal Nutrition, Sumitra Research Farm, Gujarat, India \\ *Corresponding Author E-mail: demsonfarms@yahoo.com
}

Received: 24 March 2019, Revised: 6 April 2019, Accepted: 18 April 2019

\begin{abstract}
Moringa oleifera commonly referred to as the drumstick tree is a plant from the Moringaceae family. It is a medicinal plant that was found to be loaded with different bioactive chemicals or secondary metabolites such as vitamins, minerals, saponins, alkaloids, flavonoids and carotenoids etc, which are involved in enhancing a long term health benefits. $M$. olifera is among the most promising species based on their high antioxidant activity, high contents of micro-nutrients, processing properties, ease of growing, and also on palatability, stability and shelf life of animal products. It has a relatively high protein content which varies from $24 \%-32 \%$, the leaves are used as a food source for humans and a dry season feed for animals because of the nutrient contents it contains. It has been traditionally used in the treatment of many ailments throughout the world and has been scientifically proven to act as anti-inflammatory, antibacterial, antifungal, anticancer, antiulcer, analgesics and antiepileptic drug. With the increasing popularity on the usage of Moringa olifera in the diets of animals and the positive impact recorded, this review is a collection of different works by authors on using Moringa olifera in poultry and African catfish (Clarias gariepinus).
\end{abstract}

Key words: Moringa olifera, Livestock, Growth performance, Poultry, Catfish.

\section{Introduction}

Livestock farming is a profitable business that's widespread across various parts of Nigeria. The high cost of animal feed in semi-arid countries, is a major limitation to animal production which is raised predominately under extensive systems. Therefore, utilization of alternative feed resources may be a logical and suitable strategy in low input systems (Khezri et al., 2011; Amirteymouri et al., 2015). The insatiable demand for fishery products like Tilapia, Catfish, and Mackerel (Salmon) and chicken in Nigeria has constantly selfpromoted the steady growth and expansion of the industry. These factors, coupled with the current support of institutions, the Nigerian government, and several other African countries to promote agriculture and also support livestock farmers, make the industries a lucrative agricultural business segments to venture in. In Nigeria alone, the demand for the catfish (Clarias gariepinus) is on the increase and its contribution to the gross domestic product (GDP) in 2008 stood at 4.4\%. Despite this enormous demand, most farmers have 
not been able to meet this demand because the country (Nigeria) is a food deficit nation and it is obvious that protein intake is grossly inadequate in both qualitative and quantitative terms. One of the key cardinals of livestock management is feeding, it accommodates about $70-80 \%$ of the total cost of production. There has recently been an increase in competition among ingredients used in the manufacture of livestock feed. There is consequently a great need for alternatives that can supply the high demands for such ingredients, in particular for soya meal (Chisoro, 2015; Garba et al., 2010) suggested partial or complete replacement of expensive and conventional feed ingredients with cheaper non-conventional substitutes. One of the ways of reducing the cost of production and making protein available to people in cheaper prices especially in developing countries is by the use of agricultural by-products and tropical plants (leaf meal) which are not directly used by humans as food to feed livestock (Asar et al., 2010). It has been reported that some leaf meal provides animals with necessary vitamins, minerals, oxycarotenoids and protein (Opara, 1996), for instance Moringa olifera leaves and pods are found to be loaded with vitamins and amino acids (Francis et al., 2005).

Moringa leaves have unique qualities that make it a potential replacement for soybean meal or fish meal in non-ruminant diets. Moringa oleifera commonly referred to as the drumstick tree is a plant from the Moringaceae family and it is the most widely cultivated species of the genus Moringa. Moringa oleifera is a fast-growing, deciduous tree. It can reach a height

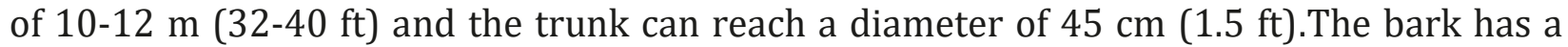
whitish-grey color and is surrounded by thick cork. Young shoots have purplish or greenish-white, hairy bark. The tree has an open crown of drooping, fragile branches and the leaves build up feathery foliage of tripinnate leaves. The flowers are fragrant and bisexual, surrounded by five unequal, thinly veined, yellowish-white petals. The flowers are about 1.0-1.5 cm (1/2) long and $2.0 \mathrm{~cm} \mathrm{(3/4)} \mathrm{broad.} \mathrm{They} \mathrm{grow} \mathrm{on} \mathrm{slender,} \mathrm{hairy} \mathrm{stalks} \mathrm{in}$ spreading or drooping later flower clusters which have a length of $10-25 \mathrm{~cm}$. The tree is often called 'multipurpose' due to the fact that all parts include leaves, pods, seeds, flowers, fruits and roots are edible (Orwa et al., 2009). According to (Onimisi et al., 2007). M. olifera can be included up to $30 \%$ in rabbit diet without any adverse effect on the growth performance. It can also be included up to $20 \%$ in the diets of laying birds without any adverse effect on their production and performance (Kakengi et al. 2007). Moringa leaves meal contains $27.51 \%$ crude protein, $19.25 \%$ crude fibre, $2.23 \%$ crude fat, $7.13 \%$ ash, $76.53 \%$ moisture, $43.88 \%$ carbohydrate and $1296.00 \mathrm{Kj} / \mathrm{g}$ calories (Oduro et al., 2008). The leaves are non-toxic and found to be loaded with nutrients necessary for the growth and development of animals.

Several studies have shown that $M$. olifera leaves are highly medicinal as they perform several functions such as being antibacterial (Egbuikwem and Sangodoyin, 2013), antifungal (Prston et al., 2010), antidiabetic, antitumor, anti-ulcer, antioxidant, anti-cancer as they are used in the treatment of the digestive system. Medicinal plants contain a vast range of pharmacologically active ingredients as each herb has its own unique combination and properties. Herbs contain ingredients which possess several effects that are combined in the one medicine (Phondani et al., 2010; Kamboj, 2000). Moringa seed powder has antibacterial properties that make it useful as a natural clarifier for water purification systems and fish ponds (Aruna and Srilatha, 2012). 
In view of the potentials of $M$. olifera, this work focuses on various researches carried out on the effect of the plant on the growth and performance of African catfish (Clarias gariepienus) and poultry.

\section{Growth performance of African catfish fed $M$. olifera leaf meal}

The growth performance ability of dried $M$. olifera leaf meal was examined in the diet of Clarias gariepinus (Akinwole et al., 2016; Kittisak et al., 2017). Ninety Clarias gariepinus juveniles with individual weight of 10 grams were stocked at 10 fish per tank per triplicates. Waste water from fish rearing pond was collected and treated with $120 \mathrm{mg} / \mathrm{L}$ of alum and Moringa seed and the supernatant water was decanted and used for fish culture. The growth performance and feed efficiency of catfish cultured with Moringa seed treated water (MSTW) did not differ ( $p>0.05$ ) from those cultured with deep well water but were higher $(\mathrm{p}<0.05)$ than those of catfishes raised with alum treated water (ATW). The MSTW catfish had higher $(\mathrm{p}<0.05)$ survival rate of $93.33 \pm 3.83 \%$ as compared to control $(90.78 \pm$ $30.64 \%)$ and ATW catfish (30.00 $\pm 26.40 \%)$. The MSTW exhibited the best performance in terms of total production per cubic metre of water used with the value of $2.64 \pm 0.46 \mathrm{Kg} / \mathrm{m}^{3}$ compared with $0.94 \pm 0.02 \mathrm{Kg} / \mathrm{m}^{3}$ and $0.82 \pm 0.61 \mathrm{Kg} / \mathrm{m}^{3}$ in the control and ATW catfish respectively.

A study was also carried out by Adewumi (2014) on fish fed diet supplemented with dried M. olifera leaf meal (MLM) at $0 \%, 5 \%$ and $10 \%$ were not significantly different ( $>0.05$ ) from one another while these were significantly different $(\mathrm{p}<0.05)$ from the performance of the fish fed diet with MLM at 20\% and 30\%. Similarly, (Kittisak et al., 2017) conducted an experiment where fish were fed with diets containing isonitrogenous $(350 \mathrm{~g} / \mathrm{kg}$ crude protein) and isoenergetic (3000 kcal $/ \mathrm{kg}$ ) supplemented with dietary Moringa leaf at $0 \mathrm{~g} / \mathrm{kg}$ fish, $100 \mathrm{~g} / \mathrm{kg}$ fish, $150 \mathrm{~g} / \mathrm{kg}$ fish and $200 \mathrm{~g} / \mathrm{kg}$ fish for 60 days. At the end of the experiment fish fed diet containing Moringa leaf at $100 \mathrm{~g} / \mathrm{kg}$ demonstrated better growth than the other inclusion levels, but it was not significantly different from the control group. The digestibility coefficient and protein digestibility were lower in fish fed with a higher inclusion of Moringa leaf in the diets $(\mathrm{p}<0.05)$, the report concluded that up to $100 \mathrm{~g} / \mathrm{kg}$ fish without any deleterious effect in the growth performance, feed utilization and digestibility of catfish.

The positive growth impact of $M$. olifera could possibly be attributed to the presence of essential nutrients in the plant. According to (Foidl et al 2001; Rweyemamu (2006); Moyoet al., 2011; Rubanza et al. 2005; Richter et al., 2003). M. olifera contains calcium, phosphorus, magnesium, potassium, iron, selenium, zinc, sodium, copper, manganese, methionine, lysine, threonine, histidine and arginine depending on the stage of harvest and species. (Richter et al., 2013) also reported that the presence of this essential minerals and amino acids improve digestibility, palatability and intake in animals.

\section{Phytochemicals in plants}

Plants produce bioactive chemicals or secondary metabolites also known as phytochemicals. About 10,000 different phytochemicals have been identified, and many still remain unknown. High concentrations of phytochemicals, which may protect against free radical damage, accumulates in plants (Naczk, 2006; Suffredini et al., 2004). Studies have shown that many plants are rich in antioxidants, vitamins especially (A, C and E), flavonoids and tannins which provide several health benefits to human and animals (Valko et al., 2006; 
Ammar et al., 2017). The synergistic combination of these phytochemicals in $M$. olifera causes an increase in feed consumption, palatability and disease prevention as presented in Table 1.

Some of the phytochemicals that have been isolated from Moringa preparations are reported to benzylsothiocyanate,4-( $a$ - $L$-rhamnopyranosyloxy) benzyl glucosinolates, 4-(4'Oacetyl-a-L-rhamnopyranosyloxy) benzyl, isothiocyanate, 4-( $a$ - $L$-Rhamnopyranosyloxy) which confers it the ability to function as antibacterial, anti-inflammatory, antiviral, antioxidant, anti-tumor, anti-cancer (Bennett et al., 2003; Atawodi et al., 2010).

Table 1. Phytochemical constituents in extract of $M$. olifera leaf and their benefits

\begin{tabular}{cccc}
\hline Constituents & Aqueous extract & Methanol extract & Benefits \\
\hline Tannins & ++ & + & Bactericidal, anti-inflammatory \\
Saponins & + & + & Antioxidant, anti-cancer \\
Alkaloids & +++ & + & Treatment of malaria \\
Flavonoids & + & + & Bactericidal, anti-inflammatory \\
Glycosides & + & - & Provide energy to the body \\
\hline
\end{tabular}

*Key: +++, highly present; ++, moderate present; +, slightly present; -, not present

Source: (Chinwe Christy Isitua et al., 2015)

\section{Alkaloids}

They are heterogeneous group of naturally occurring compounds found in the leaves, bark, roots or seeds of plants. Some alkaloids stimulate the nervous systems others can cause paralysis, elevate blood pressure or lower it. Certain alkaloids act as pain relievers, others act as tranquilizers. Others have also been noted to certain antimicrobial properties (Adesuyi et al., 2012; Rimbach et al., 2000; Terashima et al., 2002).

\section{Tannins}

Tannins are widely found in plant materials, tree and shrubs both leguminous and nonleguminous species. They are complex esters consisting of glucose core surrounded by various combinations of polyphenolic acids. Tannins occur in several plants and are more common in woody and herbaceous species. There are chemically two distinct types of tannins, the condensed tannin and the hydrolysable tannins. According to (Njidda and Ikhimioya 2012), the two types differ in their nutritional and toxic effects; the hydrolysable tannins can be absorbed in the blood stream and can cause (induce) toxicological effects and death when the concentration in the diet are high. It is well documented that the presence of secondary compounds in tannin in a wide range of shrubs species hamper their fodder potential (Makkar et al., 2003). According to (Mahansho et al., 1987), the poor palatability generally associated with high tannin in diet can be ascribed to its astringent property, which is a consequence of its ability to bind with proteins in the saliva and mucosa membrane of the mouth during feed mastication. They have been implicated in the toxicity of Accacia and Desmodium species (Bodaway and White, 1963; McCosker and Hunter, 1966).

Tannin has both positive and negative effect on the nutritive value of forage. Condensed tannins adversely affect palatability, intake, digestibility and animal performance. Tannins protein/enzyme complexes decrease rumen ammonia concentration thus inhibiting fermentation of structural carbohydrates. (Barry et al., 1987) reported that depression in 
protein and organic matter digestibility is due to the presence of tannin and cyanogenic glycosides. Tannin-protein complexes can also render protein unavailable for digestion in the small intestine, increase faecal nitrogen and lower nitrogen retention (Akingbade et al., 2004).

\section{Phenol}

Phenol is a crystalline organic compound. It is a constituents of coal tar. Dilute solutions of phenol are useful antiseptics but strong solutions of phenols are caustic and scarring to tissues. Phenols are widely used in the manufacture of resins, plastics, insecticides, explosives, dyes and detergents and as raw materials for the production of medicinal plants such as Aspirin (Michael, 2008).

\section{Flavonoids}

Flavonoids make up the largest class of phytochemicals (Du et al., 2016). In general, flavonoids can play an important role in decreasing disease risk through various physiologic mechanisms. Some of these include antiviral, anti-inflammatory, cytotoxic, antimicrobial, and antioxidant effects (Somerville et al., 2016). Mechanisms responsible for improvements in heart disease risk include improved endothelial function, decreased blood pressure, and improvements in lipid and insulin resistance (Sansone et al., 2015; Cox et al., 2000). Flavonoids can be divided into the following subclasses flavonols, flavanones, flavones, flavan-3-ols, and flavanonols (Koosha et al., 2016). Certain clinical studies have documented relationships between flavonoid consumption and decreased cancer risk. For example, research has shown a relationship between the reductions of colorectal cancer risk, which is the third most common type of cancer in the world, and the consumption of dietary flavonoids (Boeing et al., 2012; Thangapazham et al., 2016; Kotecha et al., 2016). Flavonoids have protective effects including anti-inflammatory, antioxidant, antiviral and anticarcinogenic properties (Middleton et al., 2000).

\section{Growth performance of birds fed M. olifera leaf meal}

Studies on growth performance of broilers fed Moringa leaf meal had a better weight gain when compared to birds fed control diet. (Hassan et al., 2016; Teteh et al., 2013; Donkor et al., 2013; Melesse et al., 2011; Nkukwana et al., 2014; El-Badawi et al., 2014; Onunkwo and George 2015), reported in an experiment that birds fed diets supplemented with Moringa leaf meal at $0 \%, 0.1 \%, 0.2 \%$ and $0.3 \%$. The result revealed that body weight gain increased significantly $(\mathrm{p}<0.05)$ as the level of Moringa increased; also the feed intake followed the same trend. Feed conversion ratio recorded better values as the level of Moringa leaf meal increased. (Gadzirayi et al., 2012) recommends that the inclusion of Moringa leaf meal as protein supplement in broiler diets at $25 \%$ inclusion levels produces broilers of similar weight and growth rate compared to those fed under conventional commercial feeds. Similarly, (Nihad et al., 2016; Gakuya et al., 2014; David et al., 2012) reported that broilers fed 20\% M. olifera meal showed better weight gain and feed conversion ratio than in control group. Birds fed 20\% Moringa leaf meal had 2391 grams compared to the treatment with 2133 grams.

(Abou-Elezz et al., 2011) reported that when Moringa oleifera leaf meal was supplemented at levels of up to $10 \%$ to laying hens it had no significant effect on laying percentage. 
Average egg weight significantly increased as a result of the supplementation of $M$. oleifera leaf meal when compared to a control (Ebenebe et al., 2013). Addition of $10 \%$ and $20 \%$ Moringa oleifera leaf meal to the laying hen diet, as a substitute for sunflower seed meal in Isa brown breed, significantly increased feed intake and dry matter intake and Feed conversion ratio ( $\mathrm{kg}$ egg/ $\mathrm{kg}$ feed) increased when $20 \% \mathrm{M}$. oleifera leaf meal was added to the laying hen diet (Kakengi et al., 2007). Increase in feed intake and feed conversion ratio, and at a higher level of $M$. oleifera leaf meal, are mainly due to low digestibility of energy and protein (Olugbemi et al., 2010a).

\section{Conclusion}

One of the ways to minimize the cost of feed, provide animal protein and get maximum production/performance especially in developing countries, is the use of some plants/leaves and seeds that are of high nutritional properties and beneficial when incorporated into livestock feed. The use of local, cheap and readily available materials particularly those that are not utilized by man should be given attention as the only viable alternatives to the use of conventional feedstuffs. Therefore, such potential needs to be maximized for profit maximization with least cost.

\section{References}

Adesuyi, AO, Elumm, IK, Adaramola, FB, Nwokocha AGM. (2012). Nutritional and phytochemical screening of Garcinia kola. Adv. J. Food Sci. Tech., 4(1):9-14.

Adewumi, AA. (2014). Moringaolifera as a protein supplement in Clariasgariepinus diet. Adv. Res., 2(11):580-589.

Akinwole, AO, Dauda, AO, Ololade, OA. (2016). Growth performance of African catfish juveniles reared in Waste water with Alum and Moringaolifera seed. J. Aquacul. Res. Develop., 7(12):460.

Amirteymouri, E, Khezri, A, Tahmasbi, R, Dayani, 0, Mohammadabadi, MR. (2015). Comparison of the nutritive value of Madder, Rubiatinctorum L. and Alfalfa, Medicago sativa. Using in vitro and in situ measurements. J. Liv. Sci. Technol., 3(2):27-32.

Aruna, M, Srilatha, N. (2012). Water clarification using Moring aoleifera Lam.seedas a natural coagulant. Current Biotica., 5(4):472-486.

Aruna, M, Srilatha, N. (2012). Water clarification using Moringa oleifera Lam.seedas a natural coagulant. Current Biotica., 5(4):472-486.

Atawodi, S, Atawodi J, Idakwo, G, Pfundstein B, Haubner, R, Wurtele G, Bartsch, H, Owen R. (2010). Evaluation of the polyphenol content and antioxidant properties of methanol extracts of the leaves, stem, and root barks of Moringaoleifera Lam. J. Med. Food, 13:710716.

Asar (2010). Utilization of Corn-cob meal and faba bean straw in growing rabbits diets and their performance, digestibility and economical efficiency. Egypt Poul. Sci., 2010, 30:415442. 
Bennett, R, Mellon, F, Foidl, N, Pratt, J, DuPont, M, Perkins, L, Kroon, P. (2003). Profiling glucosinolates and phenolics in vegetative and reproductive tissues of the multi-purpose trees Moringaoleifera L. (Horseradish tree) and MoringastenopetalaL. J. Agri. and Food Chem., 51: 3546-3553.

Chinsoro, P. (2015). Potential use of baobab seeds in poultry diets, department of livestock and pasture science. Faculty of Science and Agriculture, University of Fort Hare. pp 52-53.

David, LS, Vidanarachchi, JK, Samarasinghe, K, Cyril, HW, Dematawewa, CMB. (2012). Effects of Moringa based Feed Additives on the Growth Performance. Tropical Agricult. Res., 24(1):12-20.

Egbuikwem, P, Sangodoyin, A. (2013). Coagulation efficacy of Moringaoleiferaseed extract compared to alum for removal of turbidity and E. coli in three different water sources. Eur. Int. J. Sci. Technol., 2(7):13-20.

Foidl, N, Makkar, H, Becker, K. (2001). The potential of Moringa Oleifera for agricultural and industrial uses. Pp 45-76.

Francis, G, Makkar, HPS, Becker, K. (2005). Products from little researched plants as aquaculture feed ingredients retrieved febuarary 24, 2005 from http:// www.fao.org/DOCREPIARTICLE /AGRIPPA/55/FN.HTM\# Topofpage.

Gadzirayi, CT, Masamha, B, Mupangwa, JF, Washaya, S. (2012). Performance of broiler chickens fed on mature Moringaoleifera leaf meal as a protein supplement tosoyabean meal. Int. J. Poul. Sci., 11:5-10.

Gakuya, DW, Mbugua, PN, Mwaniki, SM, Kiama, SG, Muchemi, GM, Njuguna, A. (2014). Effect of Supplementation of Moringaoleifera (LAM) Leaf Meal in Layer Chicken Feed. Int. J. Poult. Sci., 13(7):379-384.

Garba, JA, VanderJagt, DJ, Pastuszyu, A, Mounkaila, G, Glew, RS, Millson, M, Glew, RH. (2010). Nutrient and chemical composition of wild plant foods of Nigeria. J. Food Composit. Anal., 13:83-92.

Hanaa, F. M. Ali, Sherein, S. Abdelgayed, Fatma, Ahmed, A, Farid. M. (2016). MoringaOleifera Leaves in Broiler Diets: Effect on Chicken Performance and Health. Food Science and Quality Management, ISSN 2224-6088 (Paper) ISSN 2225-0557 (Online) Vol.58, 2016.

Hassan, HMA, El-Moniary, MM, Hamouda, Y, Eman, FE, Amani, WY, Nafisa, AA. (2016). Effect of Different Levels of Moringa oleifera Leaves Meal on Productive Performance, Carcass Characteristics and Some Blood Parameters of Broiler Chicks Reared Under Heat Stress Conditions. Asian J. Anim Vet. Adv., 11(1):60-66.

Isitua, CC, Lozano, MJSM, Jaramillo, CJ, Dutan, F. (2015). Phytochemical and nutritional properties of dried Moringaolifera. Asian Journal of Plant Science and Research, 2015, $5(2): 8-16$.

Kakengi, A, Kaijage, J, Sarwatt, S, Mutayoba, S, Shem, M, Fujihara, T. (2007). Effect of Moringa oleifera leaf meal as a substitute for sunflower seed meal on performance of laying 
hens in Tanzania. Int. J. Poult. Sci., 9:363-367.

Khezri, A, Yoosofi-Ansari, M, MohammdAbadi, MR. (2011). Analysis the protein subunits and fractions of almond meal in comparison to soybean meal and cottonseed meal using SDS-Page electrophoresis and CNCPS method. J. Agricul. Biotechnol., 3(2):15-25.

Moyo, B, Masika, P, Hugo, A, Muchenje, V. (2011). Nutritional characterization of Moringa leaves. African J. Biotech., 10(60):1292 -1293.

Oduro, I, Ellis, WO, Owusu, D. (2008). Nutritional potential of two leaf vegetables:Moringaolifera and Ipomeabatatas leaves, Scientific Res. Essay., 3(2):57-60.

Olugbemi, TS, Mutayoba, SK, Lekule, FP. (2010). Effect of Moringa (Moringa oleifera) Inclusion in Cassava. Int. J. Poult. Sci., 9(4):363-367.

Orwa, C, Mutua, A, Kindt, R, Jamnadass, R, Anthony, S. (2009). Agro-forestry Database: a tree reference and selection guide version 4.0. World Agro-forestry Centre, Kenya. Pp 335-336. (b) Onibi, G, Folorunso, O, Elumelu, C. (2008). Assessment of partial Equi-protein replacement of soyabean meal with Cassava and Leucaena leaf meals in the diets of broiler chicken finishers. Int. J. Poult. Sci., 7:408-413.

Petrosyan, A, Papazyan, T, Nollet, L. (2006). Administration of Se as Sel-Plex on top of sodiumselenite improves fertility and hatchability of a broiler breeder flock. XII European Poultry Conference, Verona, Italy. pp 7-12.

Preston, K, Lantagne, D, Kotlarz, N, Jellison, K. (2010). Turbidity and chlorine demand reduction using alum and moringa flocculation before household chlorination in developing countries. J. Water Health, 8(1):60-70.

Puycha, K, Yuangsoi, B, Charoenwattanasak., S, Wongmaneeprateep, S, Niamphithak P, Wiriyapattanasub P. (2017). Effect of Moringa leaf supplementation on growth performance and feed utilization of Bocourti's catfish. Agricul. Natural Res., 51(4):286-291.

Richter, N, Perumal, S, Becker, K. (2003). Evaluation of nutritional quality of Moringa leaves as an alternative protein for Nile tilapia. Aquacul. J., 217(1):599-611.

Rimbach, GT, Akiyama, GQ, Matsugo, S. (2000). Inhibitory effect of fermented papaya preparation on hydroxyl rahcal generation from methylguanine. Anticance Res., 20:29072914.

Rubanza, C, Shem, M, Otsyina, E, Bakengesa. S, Ichinohe, T, Fujihara, T. (2005), Polyphenolics and tannins effect on in vitro digestibility of selected Acacia species leaves. Anim. Feed Sci. Tech., 119(1-2):129-142.

Rweyemamu, LMP. (2006). Challenges in the development of micronutrient-rich food ingredients from soya beans and Moringaoleifera leaves. In: Proceedings on Moringa and Other Highly Nutritious Plant Resources: Strategies, Standards and Markets for a Better Impact on Nutrition in Africa. Accra, Ghana. Pp 37-40. 
Rweyemamu, L. (2006). Challenges in the development of micronutrient-rich food ingredients from soya beans and Moringaoleifera leaves. In: Proceedings on Moringa and Other Highly Nutritious Plant Resources: Strategies, Standards and Markets for a Better Impact on Nutrition in Africa. Accra, Ghana. Pp 37-40.

Terashima, K, Takaya, Y, Niwa, M. (2002). Powerful antioxidative agent based on garcinoic acid from Garcinia kola. Bioorganic Med. Chem., 10(5):1619-1625.

How to cite this article: J.O. Alagbe, Role of Moringa Olifera Leaf Meal on the Growth Performance of Poultry/African Catfish-A Review. International Journal of Advanced Biological and Biomedical Research, 2019, 7(3), 237-245. Link: http://www.ijabbr.com/article 34924.html 